\title{
Evaluation of the subsoil at the sites of two aquaculture operations using electromagnetic geophysical tools
}

Ramon Wagner Torres Pena ${ }^{1}$ and Pedro Chira Oliva ${ }^{1 *}$

${ }^{1}$ Instituto de Estudos Costeiros (IECOS), Campus Bragança/UFPA, e-mail: chira@ufpa.br

Copyright 2019, SBGf - Sociedade Brasileira de Geofísica

This paper was prepared for presentation during the $16^{\text {th }}$ International Congress of the Brazilian Geophysical Society held in Rio de Janeiro, Brazil, 19-22 August 2019.

Contents of this paper were reviewed by the Technical Committee of the $16^{\text {th }}$ International Congress of the Brazilian Geophysical Society and do not necessarily represent any position of the SBGf, its officers or members. Electronic reproduction or storage of any part of this paper for commercial purposes without the written consent of the Brazilian Geophysical Society is prohibited.

\section{Abstract}

In this study, the performance of Ground Penetrating Radar (GPR) and Electromagnetic (EM-34) geophysical tools was evaluated for the characterization of the subsoil of terrains destined for the implantation of aquaculture pond. Two localities were assessed in the Brazilian state of Pará: one is a site currently being converted into an aquaculture operation (near the town of Bragança), where the Aquaculture Research Center of the Northeast of Pará (CEANPA) will be built. The other is a private aquaculture operation at Chapada, in Tracuateua with nursery and production ponds already excavated. The geophysical data indicate that the CEANPA site has a depression in the subsoil and a terrain with the conductive characteristics of sandy or argillaceous substrates. The data from Chapada indicate a water table and clayey to very clayey soils. These findings indicate that the GPR and EM-34 electromagnetic tools are adequate for the evaluation of subsoils assigned to aquaculture ventures. In particular, the analyses confirmed that the CEANPA site is adequate for the implantation of aquacultural operations.

\section{Introduction}

In recent years, the demand for fishery products has increased exponentially, leading to a vertiginous decline in the natural stocks of many species. In this context, aquaculture operations have been gaining ground around the world. Aquaculture consists of the controlled confinement of aquatic organisms at different life phases, for the management and propagation of stocks. This activity is a potentially lucrative business option, and a wide range of research has produced data on the demand for, production of, and the importation/exportation of aquaculture products (OLIVEIRA, 2009).

Aquaculture has grown considerably in Brazil in recent years, and involves not only fish farms (Pisciculture), but also operations that produce mollusks, shrimp, and even frogs (TAVARES-DIAS \& SANTOS MARIANO, 2015). FAO (2016) predicted that aquacultural production in Brazil will grow by $104 \%$ by 2025 . This study indicated that the growth in Brazilian productivity over the decade will far outpace that of Mexico (54.2\%) or Argentina (53.9\%). The report concludes that, by 2025 , an additional 29 million tons of fish will be produced, worldwide, in comparison with 2013-2015, and that almost all this additional productivity will be derived from aquaculture operations located in developing countries.

One of the most critical points in the implantation of an aquacultural operation is the analysis of the terrain on which it will be constructed, given that characteristics of the subsoil must be adequate for the infrastructure of the installation. This analysis is essential, given the costs of implantation of an operation, including labor, machinery, and other investments (DAVID \& PINHO, 2014).

The principal aspects that demand attention and assessment for the implantation of aquaculture installations include the geographic location of the site, its relief and topography, hydrological potential, soils, the construction timetable, the environmental legislation, the economic evaluation of the project, funding, and the georeferencing of the area (CAVERO \& PEREIRA, 2011; KUBITZA et al 2004).

The lack of a technologically adequate assessment of the features of the subsoil of sites destined for the installation of aquaculture operations in Pará, in particular in the Bragança region, has led to the failure of a number of projects, caused by problems ranging from the choice of inadequate production systems to the construction of deficient infrastructure. In addition to an adequate assessment of the site, the costs of the installation of an aquaculture operation may be a factor limiting this activity for small and medium producers, given not only the resources needed for sample collection and analysis, but also the time required for the final results to come through. Geophysics provides important data on the subsurface of a site, including its lithology, stratigraphy, the detection of its water table, depth of the bedrock, the presence of depressions, and the identification of faults, fractures, and other potentially important geological features (MORAES et al., 2014; CETESB, 1999).

A large number of aquaculture operations are found in the Bragança region of the Brazilian state of Pará. One example is the private installation in the community of Chapada, in the town of Tracuateua, where a number of ponds have already been excavated, and are currently productive. A second installation, the Northeastern Pará Aquaculture Center (CEANPA/UFPA-Bragança) is currently under construction at a site in the vicinity of the town of Bragança.

In the present study, these two sites were evaluated and compared using electromagnetic geophysical tools, i.e., Ground Penetrating (GPR) and an Electromagnetic meter (EM-34). The results of these analyses demonstrate that GPR and EM-34 tools can be used successfully to evaluate sites destined for future aquaculture installations.

\section{Materials and Methods}

Data were collected using Ground Penetrating Radar (GPR) and an EM-34 electromagnetic tools. 
APPLICATION OF ELETROMAGNETIC TOOLS IN AQUACULTURE

\section{Study Area}

The sites surveyed in the present study are located in the municipalities of Bragança and Tracuateua (Figure 1), in the northeastern extreme of the Brazilian state of Pará, known as the Bragança microregion. In Bragança, the study site is earmarked for the installation of the Northeastern Pará Aquaculture Center - CEANPA (310279 S; $9884370 \mathrm{~W}$ ), and is located at kilometer 2 of the highway that links the community of Engenho to Vila de Caratateua, which is approximately $8 \mathrm{~km}$ from the center of Bragança. In Tracuateua, the site is located on the property of the Gomes family (289218 S; 9895970 W), in the community of Chapada, which is approximately $22 \mathrm{~km}$ from the center of Tracuateua.

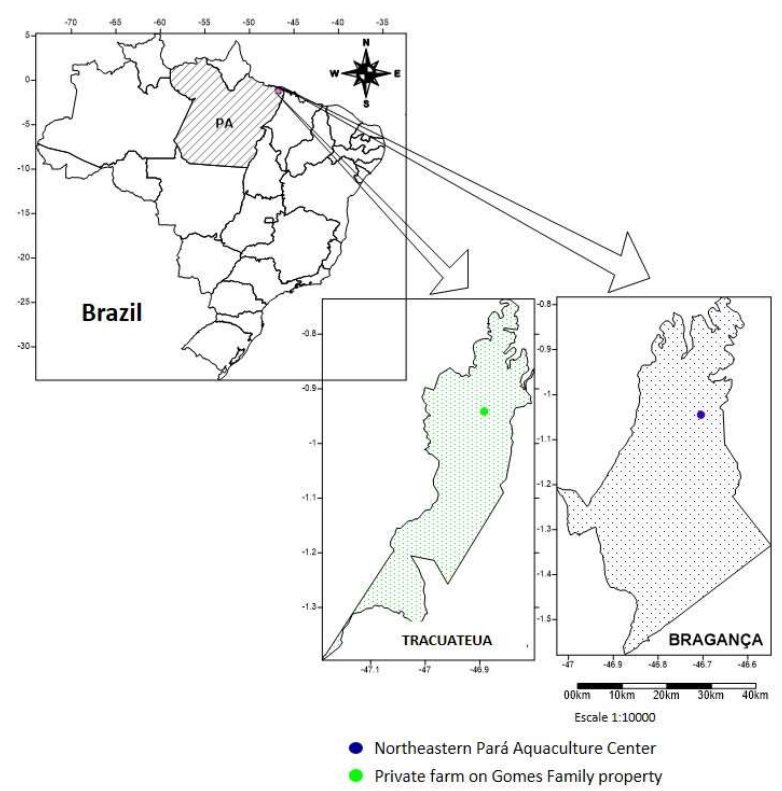

Figure 1. Map showing the sites of the aquaculture operations surveyed in the present study, in Bragança and Tracuateua municipalities, Pará (Brazil).

\section{Acquisition of the GPR data}

The GPR data were obtained using a GSSI SIR 3000 GPR, with $200 \mathrm{MHz}$ and $400 \mathrm{MHz}$ antennas, and 100, 150, 200 and 250 ns time intervals. All the profiles were georeferenced using a Garmin 76 GPS, with UTM WGS 84 coordinates.

\section{Site of the future CEANPA/UFPA}

At the future CEANPA/UFPA, which is located in the vicinity of the town of Bragança, the GPR was collected in March 2017 (rainy season). Four profiles were surveyed (Figure 2), with lengths of $240 \mathrm{~m}$ (profile $A B$, with electromagnetic pulse readings at intervals of $10 \mathrm{~m}$ ), 100 $\mathrm{m}$ (profile $\mathrm{BC}$, with electromagnetic pulse readings at intervals of $5 \mathrm{~m}$ ), $40 \mathrm{~m}$ (profile DE, with electromagnetic pulse readings at intervals of $5 \mathrm{~m}$ ), and $45 \mathrm{~m}$ (profile EF, with electromagnetic pulse readings at intervals of $5 \mathrm{~m}$ ).

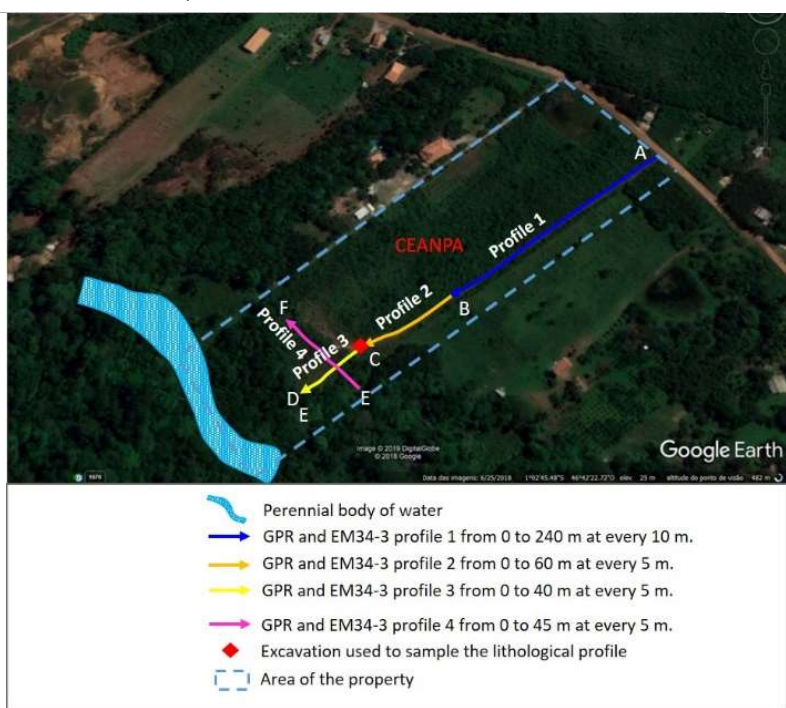

Figure 2. Satellite image of the plot on which the CEANPA/UFPA will be built, showing the GPR profiles surveyed during the present study, which were adapted to the topography of the terrain. Source: Modified from Google Earth Pro (2019).

2. Privately-owned Aquaculture operation at Chapada, Tracuateua

An active aquaculture operation is located on the Gomes family property in the community of Chapada, in Tracuateua, Pará. The GPR survey at this site followed the sample protocol as that conducted at the CEANPA/UFPA in Bragança, as described above.

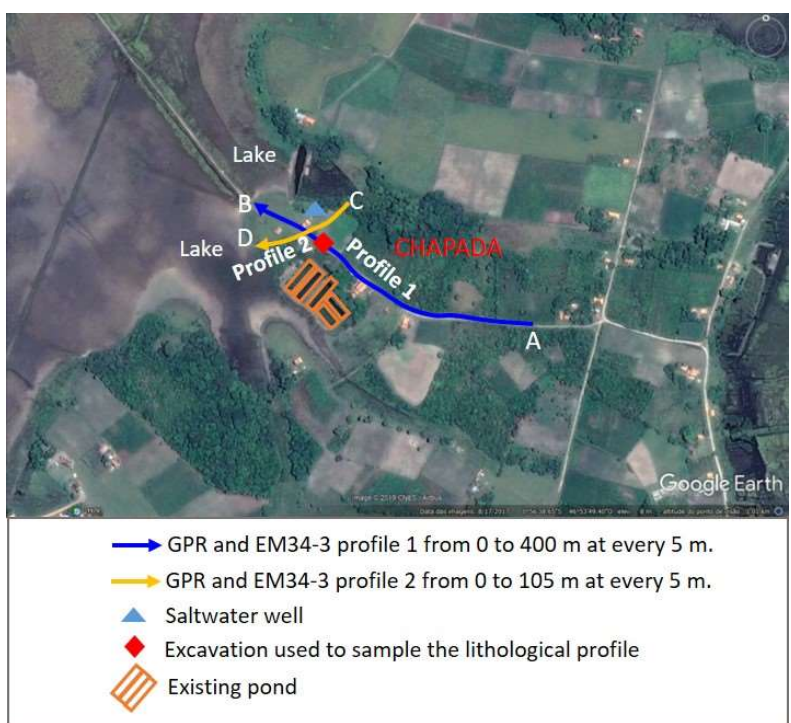

Figure 3. Satellite image of the privately-owned aquaculture operation on the land of the Gomes family in Tracuateua, Pará. Source: Modified from Google Earth Pro (2019).

The GPR data were also collected in March 2017 (rainy season) at this site. Three profiles were surveyed (Figure 3 ), with lengths of $270 \mathrm{~m}$ (profile $A B$, with electromagnetic pulse readings at intervals of $10 \mathrm{~m}$ ), $105 \mathrm{~m}$ (profile $\mathrm{BC}$, with 
electromagnetic pulse readings at intervals of $5 \mathrm{~m}$ ), and $100 \mathrm{~m}$ (profile DE, with electromagnetic pulse readings at intervals of $5 \mathrm{~m}$ ).

As the terrain has a very low gradient, the GPR profiles were established in relation to the body of water present on the property, with the profile extending from the dry land to the swampy terrain. A similar configuration was also observed at the CEANPA site.

\section{Acquisition of the EM-34 data}

The EM data were obtained using a Geonic Ltd. electromagnetic EM-34 meter. These data were also collected in March 2017. The same lines were adopted as those used for the GPR, with the same marks being used for the electromagnetic pulses. Two dipole configurations were considered: Horizontal Dipole (HD) and Vertical Dipole (VD). Similarly, two intervals (10 $\mathrm{m}$ and $20 \mathrm{~m}$ ) were considered between the coils for each dipole.

\section{Results}

The most relevant results of the GPR and EM surveys at the two study sites are given below.

1. Ground-Penetrating Radar (GPR)

\subsection{CEANPA site}

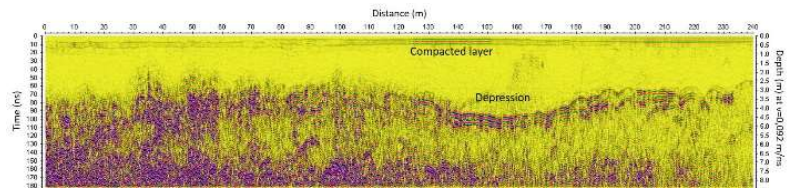

Figure 4. The 240-m long $A B$ profile, marked at $10 \mathrm{~m}$ intervals, with a $200 \mathrm{~ns}$ time window and $200 \mathrm{MHz}$ antenna.

The $A B$ profile (Figure 4 ) revealed the presence of a very abrupt depression at a depth of up to $4.75 \mathrm{~m}$, which was filled with some sort of material to $0.25-0.5 \mathrm{~m}$ of the surface. A compacted layer was also detected in the upper part of the profile, at a depth of approximately $0.25-0.50$ m.

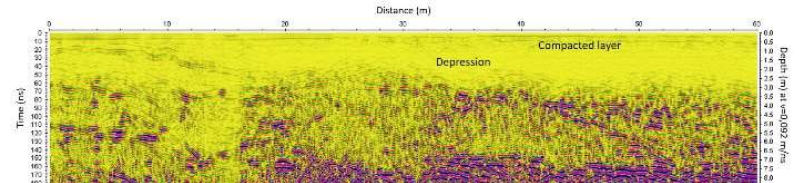

Figure 5. The $60-\mathrm{m}$ long BC profile, marked at $5 \mathrm{~m}$ intervals, with a $200 \mathrm{~ns}$ time window and $200 \mathrm{MHz}$ antenna.

The BC profile (Figure 5) revealed a depression to a depth of $3 \mathrm{~m}$ and a compacted layer near the surface at a depth of $0.25-0.5 \mathrm{~m}$

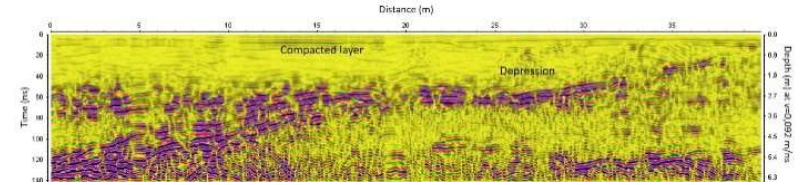

Figure 6. The 40-m long $C D$ profile, marked at $5 \mathrm{~m}$ intervals, with a $150 \mathrm{~ns}$ time window and $200 \mathrm{MHz}$ antenna.
The CD profile profile (Figure 6) was conducted along the same line as the BC profile. The only difference was the depth of the depression, which reached approximately $2 \mathrm{~m}$. This profile was conducted near a stream that runs perpendicularly to the area of the CEANPA and may be the source of water for the future installations.

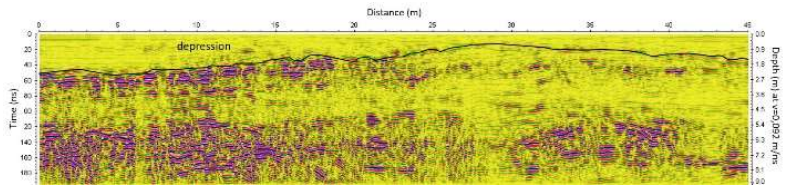

Figure 7. The 45-m long EF profile, which is perpendicular to the $C D$ profile, marked at $5 \mathrm{~m}$ intervals, with a $200 \mathrm{~ns}$ time window and $200 \mathrm{MHz}$ antenna.

The EF profile (Figure 7), which was perpendicular to the CD profile, identified a depression at a depth of up to 2.16 $\mathrm{m}$ (Figure 8).

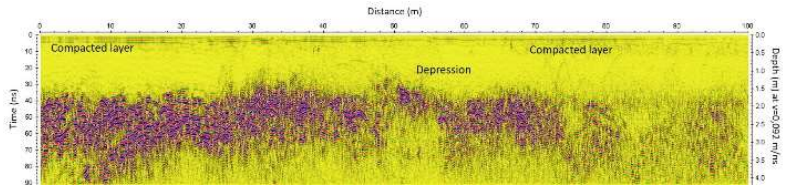

Figure 8. The 100-m long $B C D$ profile, marked at $10 \mathrm{~m}$ intervals, with a $100 \mathrm{~ns}$ time window and $400 \mathrm{MHz}$ antenna.

The BCD profile combines profiles BC and CD (Figure 8).

\subsection{Chapada site}

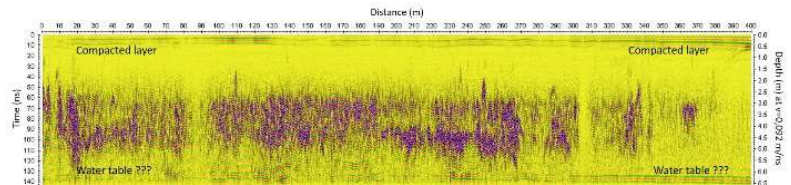

Figure 9. The 400-m long $A B$ profile, marked at $5 \mathrm{~m}$ intervals, with a $200 \mathrm{~ns}$ time window and $150 \mathrm{MHz}$ antenna.

The $A B$ profile (Figure 9) identified a set of compacted layers in the subsurface, with a thickness of approximately $0.75 \mathrm{~m}$. A strong horizontal reflector was detected at a depth of $6-6.5 \mathrm{~m}$, which may indicate the presence of a water table.

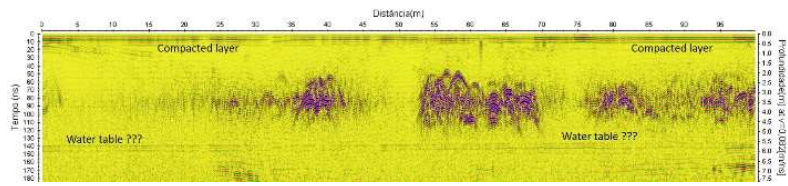

Figure 10. The 105-m long $C D$ profile, which is perpendicular to the $A B$ profile, marked at $5 \mathrm{~m}$ intervals, with a $200 \mathrm{~ns}$ time window and $200 \mathrm{MHz}$ antenna.

The CD profile (Figure 10) detected the principal characteristics of the $A B$ profile (Figure 9 ). As in this profile, a set of compacted layers with a thickness of $0.5 \mathrm{~m}$ was observed. A possible water table was also identified at a depth of $5.5-6 \mathrm{~m}$. Similarly, a number of reflectors in the form of hyperboles were detected at 1.75-5.0 m, which may indicate the presence of underground pipes or conduits. 
2. Electromagnetic data (EM-34)

\subsection{CEANPA site}

The EM data were generated at the site of the future installations of the CEANPA using two dipoles. The data from the Horizontal Dipole (HD) were produced by the antennas with $10 \mathrm{~m}$ and $20 \mathrm{~m}$ intervals between coils. The antenna with coils at $10-\mathrm{m}$ intervals revealed low levels of conductivity $(3.5-17 \mathrm{mS} / \mathrm{m})$, as did the antenna with coils at $20-\mathrm{m}$ intervals $(6-19 \mathrm{mS} / \mathrm{m})$. There values of conductivity are theoretically equivalent to depths of $7.5-15 \mathrm{~m}$, which would indicate the possible presence of saturated sand or a saturated sandy subsoil (Figures 11 and 12).
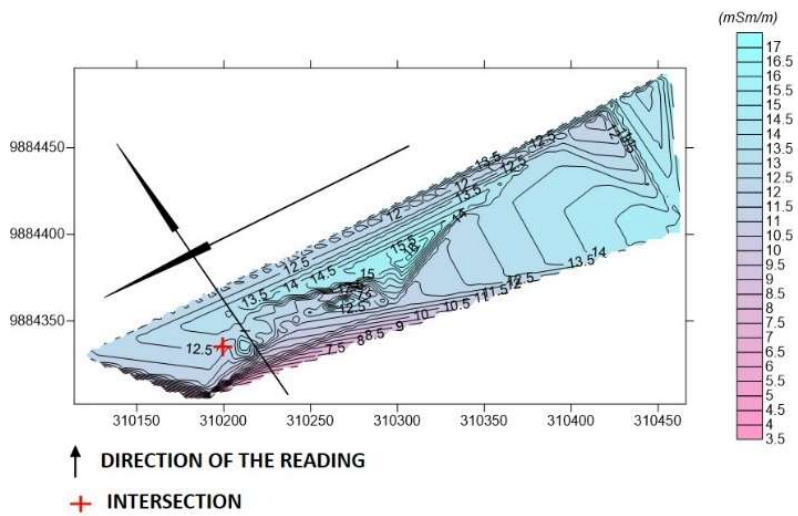

Figure 11. Map of the apparent conductivity at the CEANPA site, based on the Horizontal Dipole (HD), produced using antennas with a 10-m interval between coils.

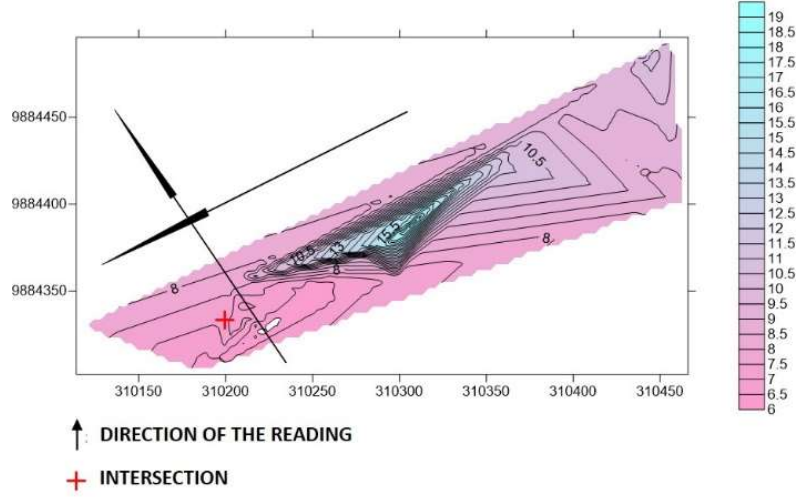

Figure 12. Map of the apparent conductivity at the CEANPA site, based on the Horizontal Dipole (HD), produced using antennas with a 20-m interval between coils.

The Vertical Dipole (VD) data were also obtained from antennas with intervals of $10 \mathrm{~m}$ or $20 \mathrm{~m}$ between coils. The antenna with coils spaced ar $10 \mathrm{~m}$ (Figure 13) revealed relatively low levels of conductivity $(3.5-13.5 \mathrm{mS} / \mathrm{m})$, and a similar result was obtained $(0.5-9.0 \mathrm{mS} / \mathrm{m})$ by the antenna with coils at $20 \mathrm{~m}$ (Figure 14). These conductivity values correspond theoretically with depths of 15-30 m, and may correspond to the presence of saturated sandy substrate.

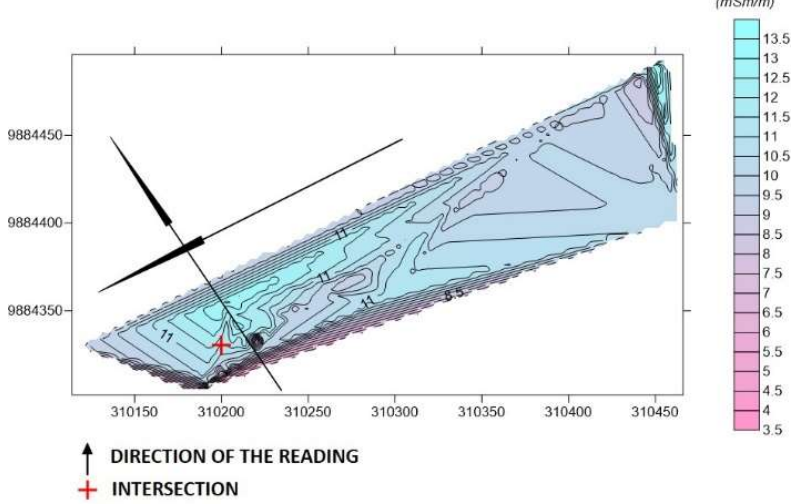

Figure 13. Map of the apparent conductivity at the CEANPA site, based on the Vertical Dipole (HD), produced using antennas with a 10-m interval between coils.

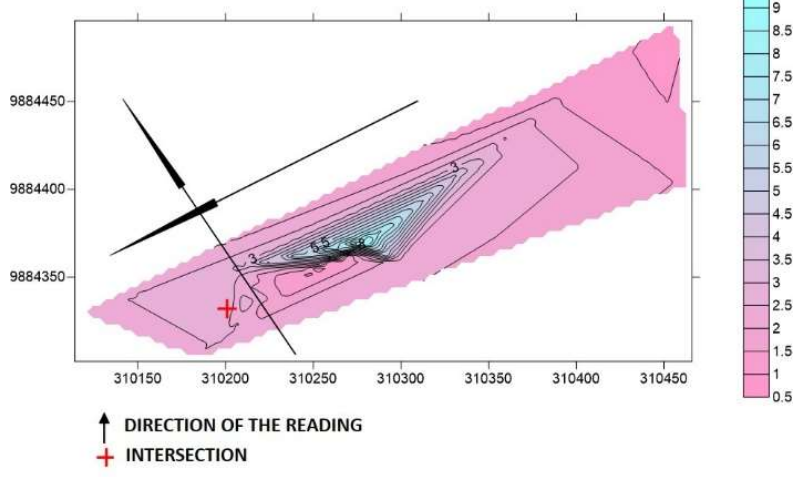

Figure 14. Map of the apparent conductivity at the CEANPA site, based on the Vertical Dipole (HD), produced using antennas with a 20-m interval between coils.

\subsection{Chapada site}

At the Chapada site, the EM data were also generated using two dipoles (HD and VD). Once again, the data from the Horizontal Dipole (HD) were obtained using coils at intervals of $10 \mathrm{~m}$ and $20 \mathrm{~m}$. The antenna with coils at $10-\mathrm{m}$ intervals recorded conductivity of between 16 and $48 \mathrm{mS} / \mathrm{m}$ (Figure 15), while the antenna with coils at 20-m intervals (Figure 16) recorded a high level of variation, i.e., -190-60 $\mathrm{mS} / \mathrm{m}$. Apparent conductivity values of between 16 and 48 $\mathrm{mS} / \mathrm{m}$ are consistent with the possible presence of a saturated sandy or clayey substrate, whereas values between -190 and $60 \mathrm{mS} / \mathrm{m}$ may indicate a subsoil of saturated sand and/or clay. 


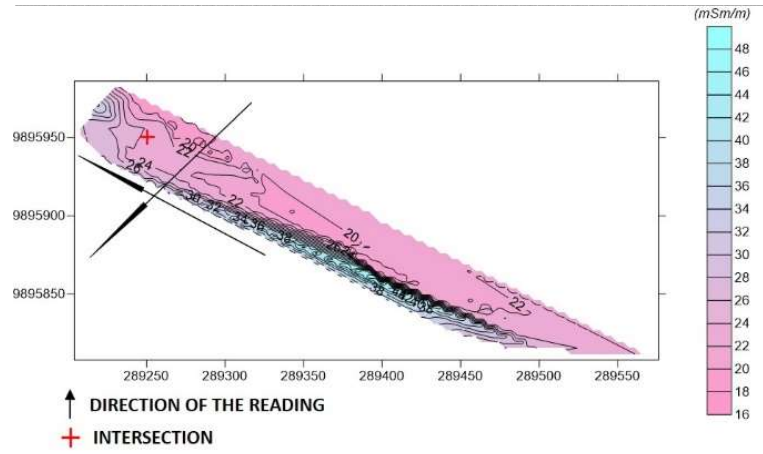

Figure 15. Map of the apparent conductivity at the Chapada site, based on the Horizontal Dipole (HD), produced using antennas with a 10-m interval between coils.

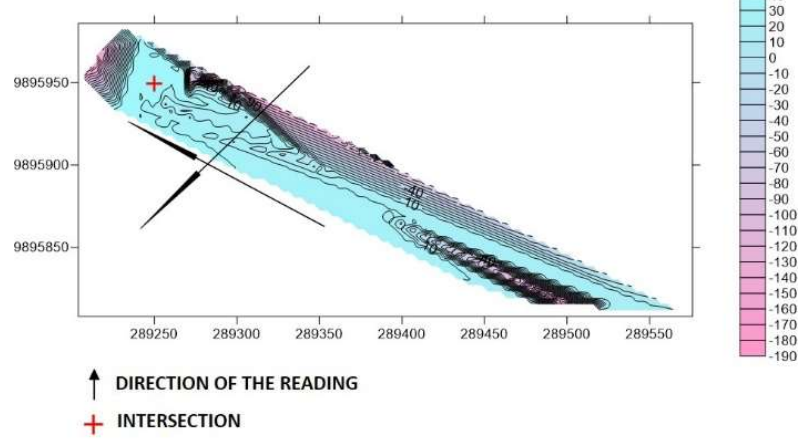

Figure 16. Map of the apparent conductivity at the Chapada site, based on the Horizontal Dipole (HD), produced using antennas with a 20-m interval between coils.

The vertical dipole (VD) data were also produced with the antennas with coils at intervals of $10 \mathrm{~m}$ and $20 \mathrm{~m}$. The antennas with the coils spaced at $10 \mathrm{~m}$ recorded positive conductivity values $(13-43 \mathrm{mS} / \mathrm{m})$. This indicate that the subsurface down to a depth of $15 \mathrm{~m}$ may be saturated sand or clay (Figure 17). The antenna with coils at 20-m intervals (Figure 18) recorded very different values, of between -180 and $70 \mathrm{mS} / \mathrm{m}$. The subsoil was surveyed to a depth of 30 $\mathrm{m}$, and may be composed of saturated sand and/or clay. The conductivity values obtained using the Horizontal Dipole were similar to those of the VD, which supports the inference of the same lithological characteristics for both dipoles.

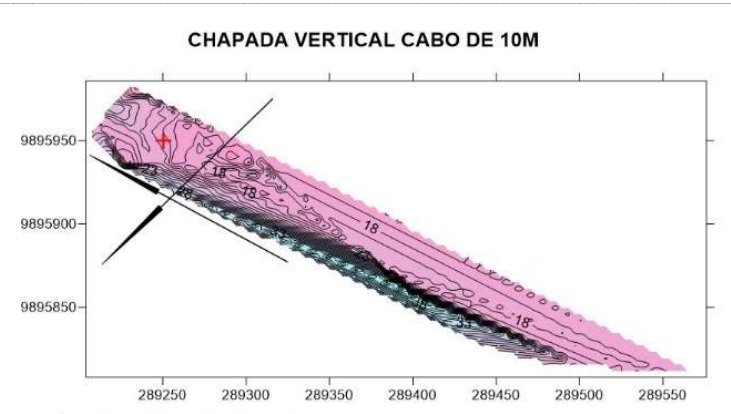

$\uparrow$ DIRECTION OF THE READING

+ INTERSECTION

Figure 17. Map of the apparent conductivity at the Chapada site, based on the Vertical Dipole (VD), produced using antennas with a 10-m interval between coils.

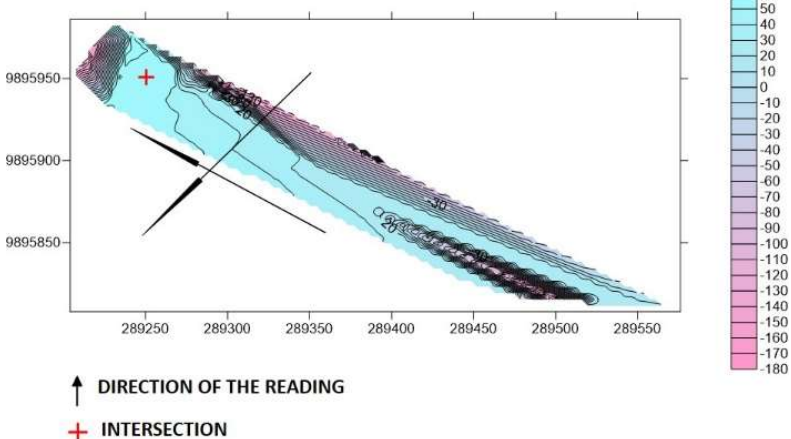

Figure 18. Map of the apparent conductivity at the Chapada site, based on the Vertical Dipole (VD), produced using antennas with a 20-m interval between coils.

\section{Conclusions \\ The GPR data}

A major depression was detected by the GPR at the future site of the Northeastern Pará Aquaculture Center (CEANPA) in Bragança, which appears to have been filled in with some type of material deposited in the past. There is also a compacted layer near the surface. No water table was detected at this site.

At the Chapada site in Tracuateua, where an aquaculture operation already exists, the GPR detected the presence of a strong horizontal reflector, which appears to indicate the presence of a water table. This can only be confirmed by drilling probes. Above this reflector, other reflectors with a hyperbolic shape may indicate the presence of pipes or conduits. A series of fine compacted layers were also detected near the surface of this site.

\section{The EM data}

The conductivity patterns recorded at the CEANPA site indicate the presence of subsoils composed of saturated sand or sandy substrates.

At the Chapada site, extremely high conductivity values were recorded, including both positive and negative ones, which may indicate the presence of saturated sand or a saturated clay subsoil, at survey depths of up to $7.5 \mathrm{~m}$. Both positive and negative values were also recorded at 
depths of up to $15 \mathrm{~m}$, which may indicate a saturated subsoil of either sand or clay.

For the vertical dipole (VD) at survey depths of up to $15 \mathrm{~m}$, the conductivity values were highly similar to those recorded previously, indicating a saturated subsoil of either sand or clay. At a survey depth of $30 \mathrm{~m}$, however, the VD conductivity values are both positive and negative, which, once again, may indicate the presence of a subsoil of either saturated sand and/or clay.

The electromagnetic methods applied in the present study permitted the evaluation of the subsoil at the two study sites (CEANPA and Chapada aquaculture operation). The results of the survey indicated that the CEANPA site is appropriate for the installation of an aquaculture operation.

\section{Acknowledgments}

We would like to thank the Faculty of Geophysics (IG/ UFPA-Belém) for the availability of the EM-34 equipment.

\section{References}

CAVERO. B. A. S., PEREIRA. T. M. Critérios para implantação de instalações para aquicultura. Universidade Federal do Amazonas/Faculdade de Ciências Agrárias/Departamento de Ciências Pesqueiras, Manaus/AM, 2011.

CETESB. Companhia Ambiental do Estado de São Paulo. Manual de gerenciamento de áreas contaminadas. São Paulo: Cetesb, 1999.

DAVID, L. H. C., PINHO S. M. Viabilidade Econômica de Projetos Aquícolas, Centro de Educação Superior da Região Sul - CERES, UNIVERSIDADE DO ESTADO DE SANTA CATARINA, Laguna, v. 1, 4p, 2014.

FAO-Organización de las Naciones Unidas para la Alimentación y la Agricultura. El estado mundial de la pesca y la acuicultura 2016. Contribución a la seguridad alimentaria y la nutrición para todos. Roma. 224p., 2016.

GOOGLE

EARTH

PRO. https://www.google.com/earth/versions/, 2019.

KUBITZA, F., ONO, E. Projetos aquícolas: planejamento e avaliação econômica. Jundiaí: Aquaimagem, 87p., 2004.

MORAES, S. L. M., TEIXEIRA C. E., MAXIMIIANO A. M. S. Guia de elaboração de planos de intervenção para o Gerenciamento de áreas contaminadas, $1^{\text {a }}$ Edição revisada, Edição IPT e BNDES São Paulo. 27p., 2014.

TAVARES-DIAS, M., SANTOS MARIANO, W. Aquicultura no Brasil: novas perspectivas. [Vol. 1]. São Carlos: Pedro \& João. Editores, 429p., 2015. 